\title{
PENGARUH POSISI FILAMEN LYCRA PADA PROSES PEMBUATAN BENANG ELASTAN TERHADAP MUTU BENANG
}

\author{
Oleh: \\ M. Fuchri ${ }^{1}$, Irwan' ${ }^{2}$, dan M. Ihsan ${ }^{3}$ \\ 1. Dosen Politeknik STTT Bandung Indonesia \\ 2. Dosen Politeknik STTT Bandung Indonesia \\ 3. Mahasiswa Politeknik STTT Bandung Indonesia
}

\begin{abstract}
ABSTRAK
Salah satu produk unggulan PT IS Tbk. adalah benang elastan yang memiliki karakteristik elastisitas tinggi dan daya serap tinggi. Karakteristik tersebut didapat dari penggabungan dua serat antara kapas dan lycra.

Filamen lycra pada proses ini dapat disebut juga sebagai benang inti dan kapas sebagai pembungkus. Proses pembungkusan benang inti didapat pada proses antara peregangan dan penggintiran, dimana kedua serat tersebut tergabung menjadi satu sehingga menghasilkan benang elastan ( $\mathrm{Ne}_{1} 40$ cotton $+40 \mathrm{D}$ lycra). Pada Departemen S pinning IV di PT IS Tbk. teknologi pemintalan benang elastan menggunakan mesin ring spinning merk Laksmi Rieter dengan alat tambahan rol pengantar v-groove merek Pinter SA. Pada proses produksi rol pengantar filamen tersebut banyak mendapat getaran dari mesin, sehingga kemungkinan posisi rol pengantar bisa berubah.

Perubahan posisi rol pengantar tersebut dapat mempengaruhi posisi filamen lycra pada benang serta memungkinkan terjadi perubahan terhadap mutu benang yang dihasilkan. Pengamatan dilakukan terhadap posisi filamen lycra pada alat tambahan v-groove, dengan percobaan pada proses produksi di mesin ring spinning dengan variasi posisi filamen lycra dengan benang kapas pada area front roll.

Setelah dianalisa dengan metoda statistik, terdapat pengaruh posisi filamen lycra pada proses pembuatan benang elastan ( $\mathrm{Ne}_{1} 40$ cotton $+40 \mathrm{D}$ lycra) terhadap mutu benang. Dengan membandingkan nilai rata-rata mutu benang yang dihasilkan dan menyesuaikan dengan standar mutu perusahaan maka dapat disimpulkan bahwa terdapat pengaruh dari perubahan posisi rol pengantar terhadap mutu benang karena dengan semakin jauhnya posisi filamen menghasilkan kekuatan tarik benang tertinggi $(16,14 \mathrm{cN} / \mathrm{Tex})$, mulur benang tertinggi $(6,93 \%)$, mempunyai nilai kerataan tertinggi $(10,54 \%)$ dan komposisi filamen lycra tertinggi $(11,96 \%)$.

Berdasarkan hasil pengujian posisi $1 \mathrm{~mm}$ dan $2 \mathrm{~mm}$ menunjukan mutu benang terhadap kekuatan, mulur, ketidakrataan masih memenuhi standar, namun hanya posisi tengah yang komposisi lycranya memenuhi standar. Hal tersebut dapat mengganggu proses selanjutnya yaitu cacat belang pada kain. Untuk menanggulangi pergeseran rol pengantar maka proses maintenance pengontrolan proses harus berjalan secara rutin, dengan sistem perawatan dan tindak lanjut yang jelas pelaksanaanya serta terjadwal, sehingga penanggulangan pergeseran rol dapat ditangani dengan cepat.
\end{abstract}

Kata kunci : Filamen Lycra, benang Elastan, kekuatan tarik, mulur dan ketidakrataan

\begin{abstract}
One of the excellent products of PT IS Tbk. is an elastant yarn that has high elasticity and high absorption characteristics. These characteristics are derived from the incorporation of two fibers between cotton and lycra. The lycra filaments in this process can also be referred to as the core yarn and cotton as a wrapper. The core thread wrapping process is obtained in the process between stretching and twisting, where the two fibers are combined into one to produce elastant yarn ( $\mathrm{Nel} 40$ cotton $+40 \mathrm{D}$ lycra). At Spinning IV Department at PT IS Tbk. elastant yarn spinning technology using Laksmi Rieter ring spinning machine with an introduction tool roller v-groove brand Pinter SA. In the process of producing the introductory rollers the filaments get a lot of vibrations from the machine, so the possibility of the introduction roller position may change.

Changes in the position of the introductory rollers may affect the position of the lycra filaments in the yarn and allow changes in the quality of the resulting yarn. Observations were made on the position of the lycra filament
\end{abstract}


in the v-groove enhancement, with experiments on the production process in the ring spinning machine with variation of the lycra filament position with the cotton yarn on the front roll area.

After analyzed by statistical method, there is influence of lycra filament position in elastant yarn making process (Ne1 40 cotton $+40 \mathrm{D}$ lycra) to yarn quality. By comparing the average value of the resulting yarn quality and adjusting to the company's quality standard, it can be concluded that there is an effect of the change of the introductory roller position on the quality of the yarn because with further filaments the highest tensile strength (16.14 cN / Tex) the highest yarn extension $(6.93 \%)$, has the highest flatness value $(10.54 \%)$ and the highest lycra filament composition (11.96\%).

Based on the results of testing the position of $1 \mathrm{~mm}$ and $2 \mathrm{~mm}$ indicates the quality of the yarn against strength, elongation, unevenness still meets the standards, but only the middle position of the lycra composition meets the standards. This can interfere with the next process of defective stripes on the fabric. To overcome the shift of the introductory rollers the process of maintenance of process control should be run on a regular basis, with a clear maintenance and follow-up system in the implementation and scheduled, so that the roller shift handling can be handled quickly.

Keywords: Lycra filament, Elastant yarn, tensile strength, elongation and evenness 


\section{PENDAHULUAN}

Salah satu produk unggulan PT IS Tbk. adalah benang elastan yang memiliki karakteristik elastisitas tinggi dan daya serap tinggi. Karakteristik tersebut didapat dari penggabungan dua serat antara cotton dan lycra.

Filamen lycra pada proses ini dapat disebut juga sebagai benang inti dan cotton sebagai pembungkus. Proses pembungkusan benang inti didapat pada proses antara peregangan dan penggintiran, dimana kedua serat tersebut tergabung menjadi satu sehingga menghasilkan benang elastan ( $\mathrm{Ne}_{1} 40$ cotton $+40 \mathrm{D}$ lycra). Pada Departemen Spinning IV di PT IS Tbk. teknologi pemintalan benang elastan menggunakan mesin ring spinning merek Laksmi Rieter dengan alat tambahan rol pengantar filamen v-groove merk Pinter SA. Pada proses produksi rol pengantar filamen tersebut banyak mendapat getaran dari mesin, sehingga kemungkinan posisi rol pengantar bisa berubah.

Perubahan posisi rol pengantar tersebut dapat mempengaruhi posisi filamen lycra serta memungkinkan terjadi perubahan pada mutu benang yang dihasilkan. Tindakan yang bersifat antisipasi sudah dilakukan oleh pabrik yaitu berupa maintenance dengan mengamati posisi rol pengantar, namun tindakan lanjutan dari hasil pengamatan tersebut kurang maksimal, karena tindakan lanjutan tidak dilakukan secara berkala.

Getaran mesin ring spinning yang cukup tinggi dari aktifitas mesin, Memungkinkan posisi rol pengantar dan filamen lycra berubah. Perubahan posisi rol pengantar tersebut membuat beberapa pertanyaan :

1. Apakah perubahan posisi filamen lycra pada proses pembuatan benang elastan ( $\mathrm{Ne}_{1} 40$ cotton $+40 \mathrm{D}$ lycra) berpengaruh terhadap mutu benang?

2. Posisi filamen manakah yang paling sesuai untuk memproses benang elastan ( $\mathrm{Ne}_{1} 40$ cotton $+40 \mathrm{D}$ lycra)?

Aktifitas mesin ring spinning bekerja kurang lebih 24 jam dalam sehari, berdampak pada mesin dan peralatan yang terpasang pada mesin. Peralatan yang terpasang akan mendapatkan getaran dari aktifitas mesin tersebut. Salah satu peralatan yang mendapatkan dampak dari aktifitas/getaran mesin adalah peralatan tambahan rol penghantar filamen v-groove merek Pinter SA.

Peralatan tambahan rol penghantar filamen v-groove merupakan alat yang menentukan posisi filamen. Posisi filamen tersebut mempengaruhi benang stuktur/bentuk filamen inti lycra dalam benang elastan yang dihasilkan, yaitu kekuatan tarik, mulur, ketidakrataan dan komposisi filamen lycra pada benang. Posisi rol penghantar normal yaitu saat posisi filamen terdapat di tengah.

Tindakan antisipasi oleh pabrik yaitu berupa maintenance dengan mengamati posisi rol pengantar v-groove, namun tindakan lanjutan dari hasil pengamatan tersebut kurang maksimal, karena tindakan lanjutan tidak dilakukan secara berkala. Tindakan lanjutan maintenance yang kurang maksimal tersebut dapat berdampak bertambah banyaknya penyimpangan pergeseran rol penghantar v-groove. Pada saat rol pengantar mengalami getaran pada kondisi tertentu (waktu tertentu) rol tersebut bisa bergeser akibat getaran tersebut. Pergeseran rol penghantar v-groove tersebut akan membuat posisi penyetelan filamen akan berubah, sehingga memungkinkan mempengaruhi mutu benang yang di hasilkan.

Pengujian yang dilakukan untuk membuktikan hipotesis tersebut yaitu pengujian kekuatan benang, mulur, ketidakrataaan benang dan komposisi filamen lycra pada benang elastan sebagai pembuktian bahwa posisi filamen lycra mempengaruhi mutu benang yang dihasilkan. 


\section{METODA PENELITIAN}

Pengamatan dilakukan pada benang hasil dari ring spinning merek Laksmi Rieter nomor 42. Produksi yang dihasilkan adalah benang elastan ( $\mathrm{Ne}_{1} 40$ cotton $+40 \mathrm{D}$ lycra), dengan bahan baku sliver roving cotton $\mathrm{Ne}_{1}$ 0,85 dan Filamen lycra $40 \mathrm{D}$.

Pengujian yang dilakukan antara lain:

1. Uji kekuatan tarik benang.

2. Uji mulur benang.

3. Uji ketidakrataan benang.

4. Uji komposisi filamen lycra pada benang.

Setting pada mesin ring spinning yang tidak berubah adalah:

1. Break draft dan total draft.

2. Jarak jepit antar pasangan rol peregang.

3. Twist multiplyer.

4. Kecepatan front bottom roll.

5. Kecepatan spindle.

\subsection{Metodologi pengamatan}

Pengamatan dilakukan di Departemen Spinning PT IS Tbk. Bahan baku benang diperoleh dari hasil produksi ring spinning merek Laksmi Rieter nomor 42, dengan peralatan tambahan rol penghantar filamen v-groove merek Pinter SA. Produksi yang dihasilkan adalah benang elastan (Ne1 40 cotton + 40 D Lycra), dengan bahan baku sliver roving cotton Ne1 0,85 dan Filamen Lycra 40 D.

Metodologi pengamatan yang dilakukan untuk mendapatkan data dan informasi yang diperlukan pada pengamatan ini adalah sebagai berikut.

1. Pengamatan secara langsung pada mesin ring spinning yang terdiri dari :

- Pengamatan pada proses produksi di mesin ring spinning dengan variasi posisi filamen lycra dengan benang cotton pada area front roll.

- $\quad$ Pengamatan terhadap posisi filamen lycra pada rol penghantar v-groove.

2. Studi pustaka untuk memperoleh informasi yang berhubungan dengan masalah tersebut yang dapat dijadikan referensi.

3. Melakukan pengujian pengamatan meliputi :

- Pengujian kekuatan tarik benang.

- Pengujian mulur benang.

- Pengujian ketidakrataan benang.

- Pengujian komposisi serat pada benang.

\subsection{Persiapan Pengamatan}

Sebelum melakukan percobaan maka perlu dilakukan persiapan-persiapan terlebih dahulu. Apabila tujuan kita adalah mendapatkan hasil yang maksimal serta sesuai dengan rencana pengamatan, perlu senantiasa mempersiapkan segala hal yang dibutuhkan serta berkaitan dengan pengamatan yang telah direncanakan, beberapa diantaranya adalah bahan baku dan mesin yang akan digunakan untuk pengamatan.

\subsubsection{Persiapan Bahan Baku}

Bahan baku material yang digunakan pada pengujian ini adalah : 


\section{Serat Cotton}

- Kenampakan : Semi dull

- Kehalusan $\quad: 1,4$ denier

- Panjang serat $\quad: 38 \mathrm{~mm}$

- Berat/bal : $250 \mathrm{~kg}$

- Asal Bahan : Australia, Amerika, Brazil

\section{Serat filamen lycra}

- Kehalusan : 40 denier

- Asal bahan : Amerika

\subsubsection{Persiapan Mesin Dan Elemen Uji Pada Mesin}

\subsubsection{Spesifikasi Mesin Ring Spinning}

Mesin ring spinning yang digunakan sebagai objek pengamatan penulis adalah mesin ring spinning dengan spesifikasi sebagai berikut :

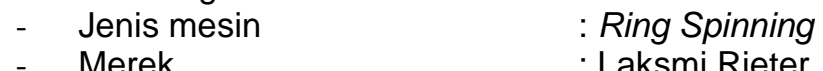

Merek : Laksmi Rieter

- Tipe : : $5 / 1$

- Buatan/tahun : India

- Jumlah spindle/mesin $\quad: 528$

- RPM : 20.000

- Diameter ring flange $\quad: 38 \mathrm{~mm}$

- Pembebanan :2,1 bar

Diameter rol peregang bawah

- Rol depan : $27 \mathrm{~mm}$

- Rol tengah $\quad: 27 \mathrm{~mm}$

- Rol belakang $\quad: 27 \mathrm{~mm}$

Diameter rol peregang atas

- Rol depan : $: 30 \mathrm{~mm}$

- Rol tengah $\quad: 30 \mathrm{~mm}$

- Rol belakang $\quad: 30 \mathrm{~mm}$

$\begin{array}{lll}\text { - } & \text { Nomor traveller } & : 6 / 0 \\ \text { - } & \text { Tebal karet apron } & : 1,05 \mathrm{~mm}\end{array}$

- Jarak jepit antara rol tengah dengan rol belakang $\quad: 42,5 \mathrm{~mm}$

- Jarak jepit antara rol tengah dengan rol depan :65 mm

\subsubsection{J enis alat tambahan v-groove}

- Merek

- Buatan

- Tahun
: Pinter SA

: Spanyol

: 1997

\subsection{Pelaksanaan Pengamatan}

Setelah mempersiapkan bahan baku maka langkah selanjutnya adalah melakukan percobaan dengan prosedur sebagai berikut;

\subsubsection{Penyetelan Posisi Filamen Terhadap Roving}

Perubahan yang dilakukan pada penyetelan posisi filamen lycra pada alat v-groove tersebut. Perubahan tersebut dilakukan dengan cara sebagai berikut:

\subsubsection{Persiapan pengambilan sampel}

1. Dengan tiga perlakuan terhadap penyetelan posisi filamen lycra pada roving, maka direncanakan pengambilan sampel sebanyak 10 bobin, terhadap 10 populasi yang ada pada tiap setting posisi.

2. Menandai bobin tiap variasi penyetelan yang berbeda.

3. Percobaan dilakukan dengan durasi waktu 3 jam 1 kali doffing, sebanyak 10 bobin tiap setting posisi.

4. Setelah itu dilakukan pengujian benang.

\subsubsection{Penyetelan Penghantar Filamen}


1. Pastikan agar adanya kesamaan posisi antara penghantar filamen dan penghantar roving.

2. Atur posisi filamen lycra pada roving sesuai dengan variasi posisi yang akan dicoba. Caranya kendorkan baut pada tension dengan mempergunakan kunci $L$ (ukuran 2.5).

3. Kencangkan kembali baut pada tension setelah mendapatkan posisi yang sesuai, dimana fungsi tension tersebut berfungsi menjaga tegangan filamen yang jatuh di atas top front roll.

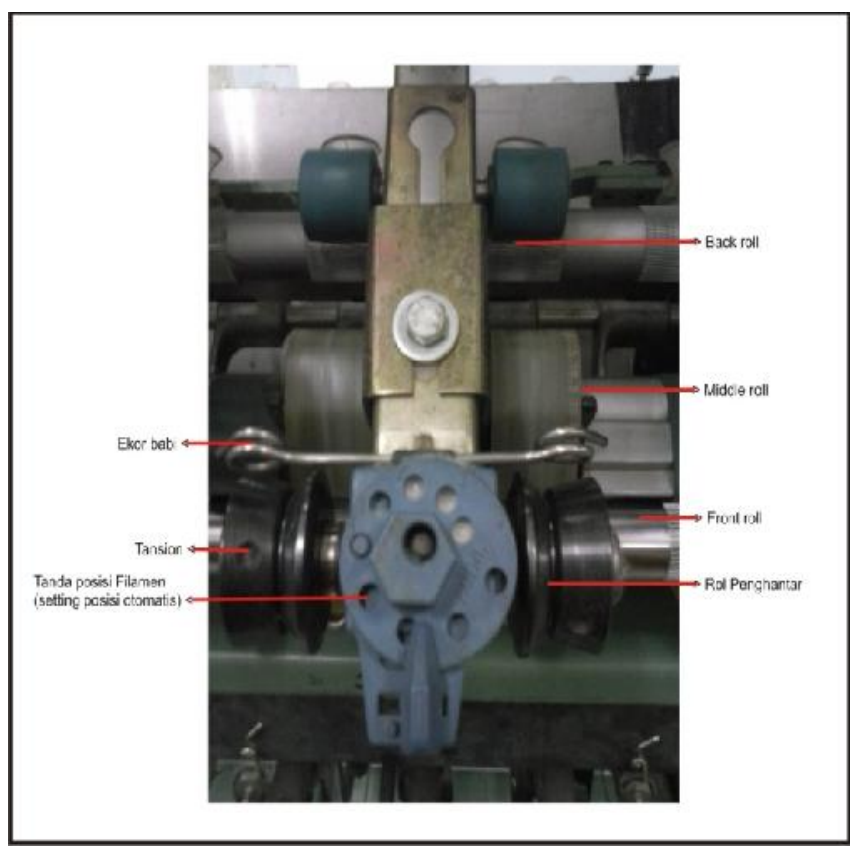

Gambar 2.1 Bagian Alat Penghantar Pinter S.A

\section{HASIL DAN PEMBAHASAN}

\subsection{Hasil pengamatan}




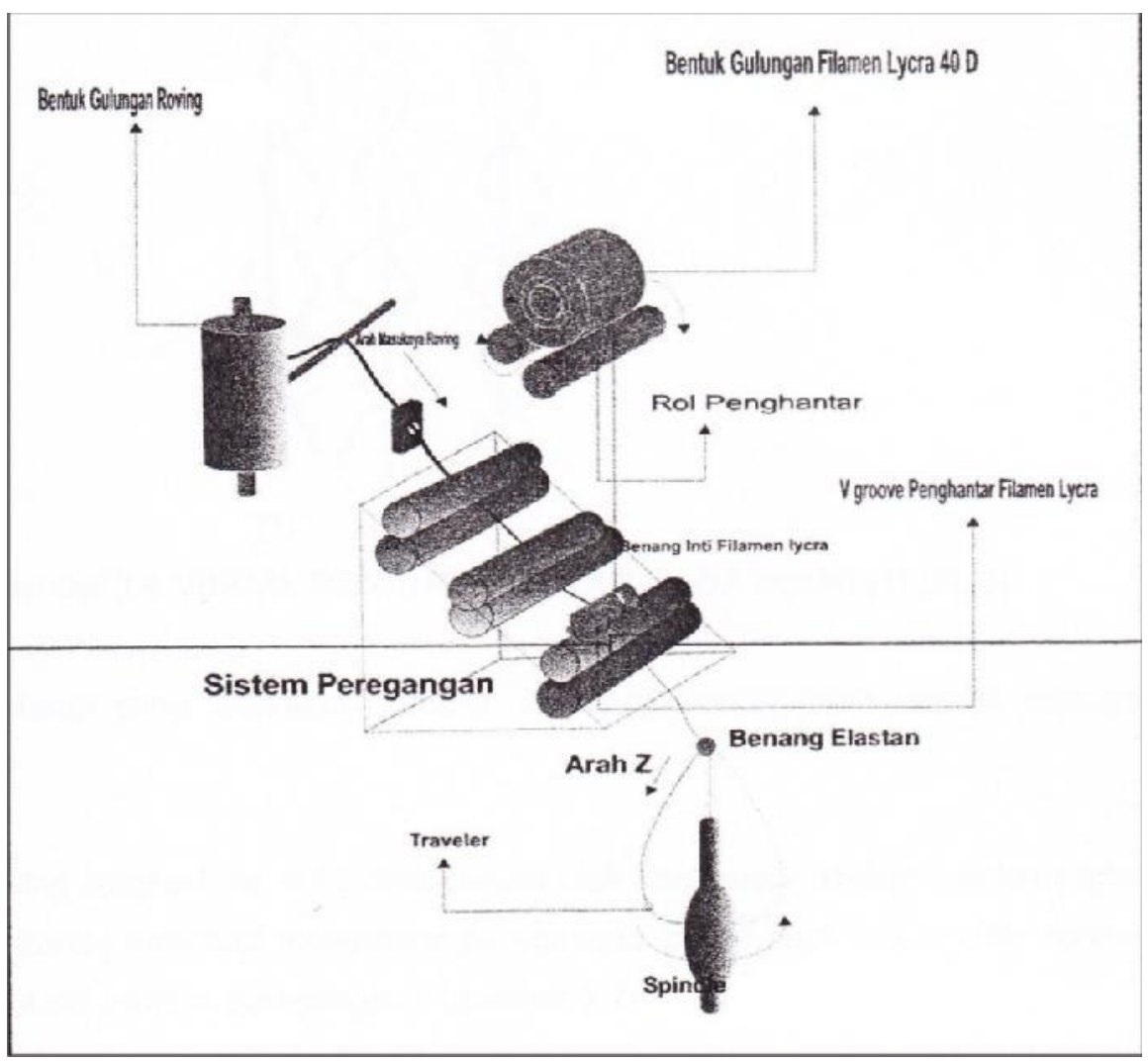

Gambar 3.1 Percobaan Pembuatan Benang Elastan

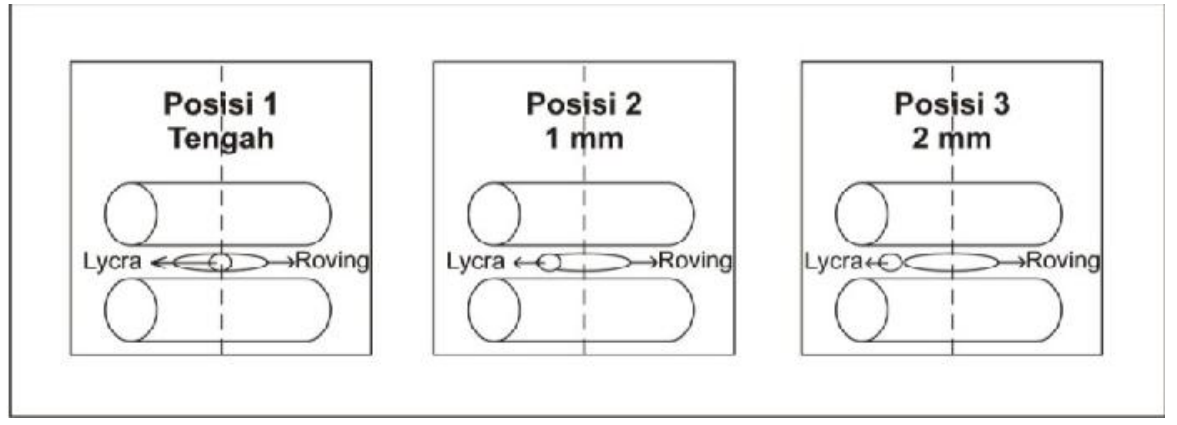

Gambar 3.2 Variasi Posisi pada Percobaan Benang Elastan 

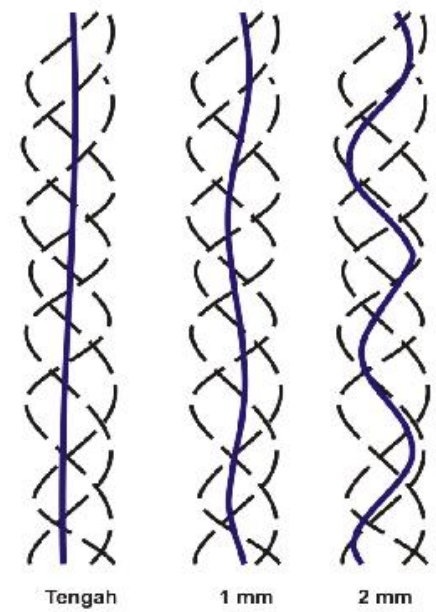

\section{Gambar 3.3 Visual Benang Elastan pada 3 Posisi Variasi}

Dari percobaan yang dilakukan, maka diperoleh hasil sebagai berikut:

1. Roving combed $\mathrm{Ne}_{1} 0.853$ dihantarkan oleh kondensor (dalam keadaan tidak bergerak) sebelum mengalami perenggangan pada; back roll, middle roll, dan front roll (system perenggangan). (gambar 3.2).

2. Filamen lycra 40 Denier sendiri dihantarkan oleh roll penghantar filamen v-groove langsung menuju front roll (dengan setting posisi tertentu). (gambar 3.2).

3. Terbentuknya benang elastan pada front roll merupakan proses penggabungan kedua serat tersebut. (gambar 3.2).

4. Penyetelan posisi pada filamen pada front roll dapat dilihat pada gambar 3.3, dimana terlihat variasi posisi $(1,2,3)$ filamen lycra.

5. Setelah terjadinya penggabungan roving dan filamen, maka terjadilah pergintiran dan benang elastan tersebut di gulung dalam bentuk bobin.

\subsection{Pengujian Ketidakrataan dan $\mathrm{Ne}_{1}$ Roving}

Berikut adalah data hasil dari pengujian ketidakrataan roving dan nomor roving yang telah diuji :

\section{Tabel 3.1 Hasil Pengujian U\% dan $\mathrm{Ne}_{1}$ Bahan Baku Roving}

\begin{tabular}{|c|c|c|}
\hline Statistik & $\mathbf{U} \%$ & $\mathbf{N e}_{\mathbf{1}}$ \\
\hline $\mathbf{N}$ & 10 & 10 \\
\hline $\boldsymbol{\Sigma}$ & 123.79 & 8.53 \\
\hline$\overline{\boldsymbol{X}}$ & 12.38 & 0.85 \\
\hline $\mathbf{S D}$ & 0.03 & 0.00 \\
\hline $\mathbf{C V}$ & 0.21 & 0.57 \\
\hline $\mathbf{E}$ & 0.13 & 0.35 \\
\hline
\end{tabular}

\subsection{Pengujian Kekuatan Tarik Per Helai Benang (cN/tex)}

Pengujian kekuatan tarik per helai benang (cN/tex) dilakukan untuk mengetahui apakah terdapat pengaruh variasi posisi filamen lycra terhadap kekuatan tarik benang per helai (cN/tex). Pengujian dilakukan terhadap 3 variasi yang diujikan, berikut adalah data statistik dari hasil pengujian tersebut.

Tabel 3.2 Hasil Pengujian Kekuatan Tarik Benang Per Helai (cN/tex)

\begin{tabular}{|c|c|c|c|c|}
\hline \multirow{2}{*}{ Ket. } & \multicolumn{2}{|c|}{ Posisi Lycra (cN/tex) } & \multirow{2}{*}{ Standar } & \multirow{2}{*}{ Toleransi } \\
\cline { 2 - 3 } & Tengah & $1 \mathrm{~mm}$ & $\mathbf{m m}$ & \\
\hline
\end{tabular}




\begin{tabular}{|c|c|c|c|c|c|}
\cline { 2 - 4 } $\mathbf{N}$ & 10 & 10 & 10 & - & - \\
\hline $\mathbf{\Sigma}$ & 135,08 & 153,67 & 161,43 & & $-5 \%(13,49)$ \\
\hline$\overline{\boldsymbol{x}}$ & 13,51 & 15,37 & 16,14 & 14,20 & - \\
\hline $\mathbf{S D}$ & 0,40 & 0,57 & 0,84 & & - \\
\hline $\mathbf{C V}$ & 2,98 & 3,73 & 5,18 & - & \\
\hline $\mathbf{E}$ & 1,86 & 2,33 & 3,24 & & \\
\hline
\end{tabular}

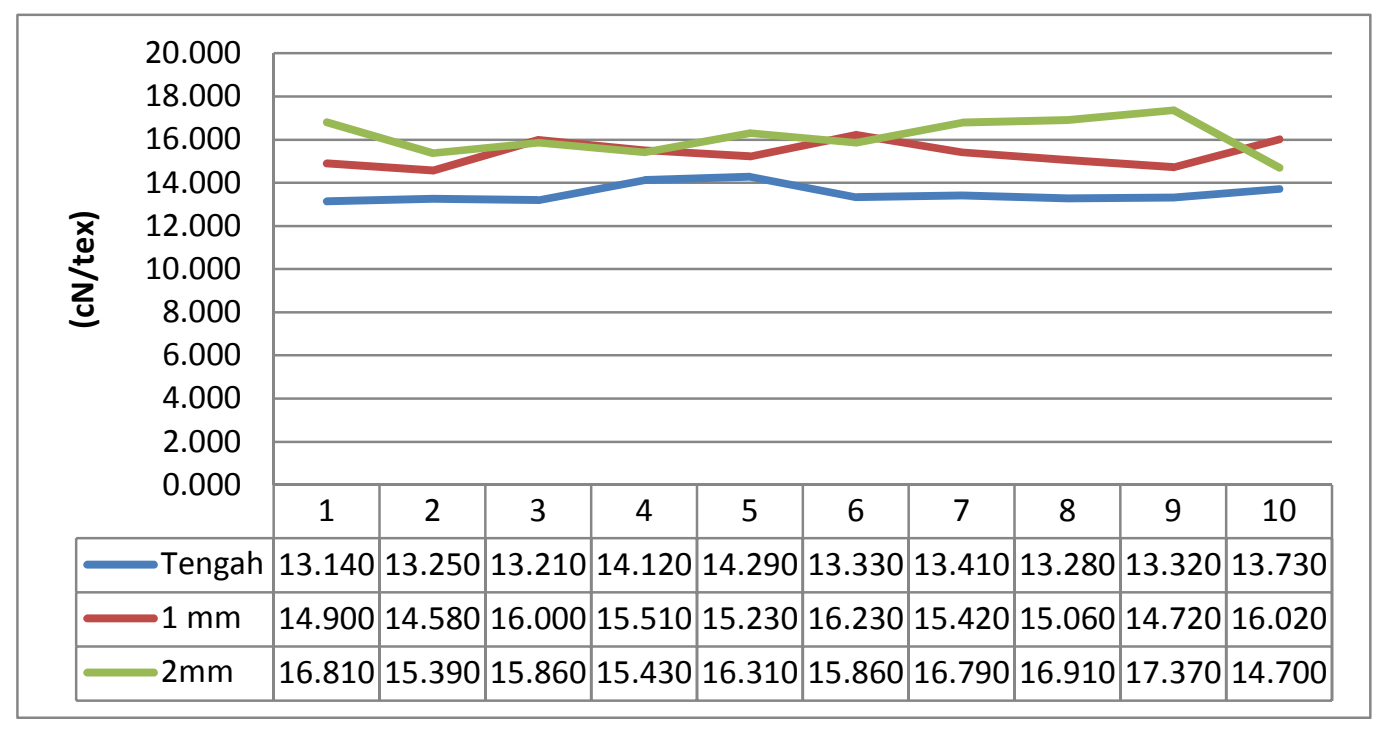

\section{Gambar 3.4 Kekuatan Tarik Benang (cN/Tex)}

Grafik diatas menunjukan nilai kekuatan tarik benang akibat dari perubahan posisi filamen lycra, berdasarkan grafik diatas, semakin posisi lycra jauh dari posisi tengah maka kekuatan benang semakin baik. Hal ini karena komposisi lycra di posisi paling jauh yaitu $2 \mathrm{~mm}$ sangat banyak, yang menyebabkan ketika benang elastan ditarik kekuatan menahan beban hingga benang putus sangat tinggi.

Untuk mengetahui sejauh mana pengaruh perbedaan hasil variasi posisi filamen lycra terhadap kekuatan tarik benang per helai (cN/tex), maka dilakukan pengolahan data statistik dengan menggunakan metoda Analisis Variasi (ANAVA). Pada tabel 3.3 dapat dilihat hasil daftar pengolahan data uji statistitika dengan menggunakan uji anava satu arah kekuatan tarik benang per helai (cN/tex) dari penggunaan variasi posisi filamen lycra.

Tabel 3.3 Hasil Pengujian Anava Kekuatan Tarik Benang Per Helai (cN/tex)

\begin{tabular}{|c|c|c|c|c|c|c|}
\hline $\mathrm{F}_{\text {tabel }}$ & 3,35 & Sumber Variasi & DK & JK & KT & $F_{\text {hitung }}$ \\
\hline Ry & 675,40 & Rata-Rata & 1 & 675,40 & 6755,40 & \multirow{3}{*}{46,17} \\
\hline Ay & 36,67 & Antar Kelompok & 2 & 36,67 & 18,34 & \\
\hline Dy & 10,72 & Dalam Kelompok & 27 & 10,72 & 0,40 & \\
\hline $\mathrm{Y}^{2}$ & 6802,79 & Total & 30 & 6802,79 & & \\
\hline
\end{tabular}

Kesimpulan :

Harga $F$ hitung (46.17) kemudian dibandingkan dengan harga $F$ tabel (3.35). Jadi, $F$ hitung $>F$ tabel, sehingga Ho ditolak dan Ha diterima. Kesimpulannya adalah variasi posisi filamen lycra berpengaruh terhadap nilai kekuatan tarik benang per helai yang dihasilkan. Untuk mengetahui variasi mana saja yang menunjukkan 
perbedaan yang signifikan, dilakukan uji Newman Keuls terhadap data diatas. Berikut data uji rentang newman keuls hasil perhitungan.

Tabel 3.4 Uji Newman Keuls Kekuatan Tarik Benang Per Helai

\begin{tabular}{|c|l|l|}
\hline & $\mathbf{P}$ & $\mathbf{R S T}$ \\
\hline $\mathbf{2}$ & 2.90 & 0.58 \\
\hline $\mathbf{3}$ & 3.51 & 0.70 \\
\hline $\mathbf{S y}$ & 0.1993 & \multicolumn{2}{|c|}{} \\
\hline
\end{tabular}

\begin{tabular}{|c|c|c|c|}
\hline Perbandingan & Selisih & RST & Nilai \\
\hline tengah vs $1 \mathrm{~mm}$ & 1.86 & 0.58 & Tolak \\
\hline tengah vs $2 \mathrm{~mm}$ & 2.64 & 0.70 & Tolak \\
\hline $1 \mathrm{~mm}$ vs $2 \mathrm{~mm}$ & 0.78 & 0.58 & Tolak \\
\hline
\end{tabular}

Dari tabel 3.4 di atas, dapat ditarik kesimpulan bahwa ada perbedaan kekuatan tarik benang per helai dari setiap perbandingan. Perbandingan yang paling signifikan adalah perbandingan antara posisi filamen lycra tengah dengan posisi filamen lycra $2 \mathrm{~mm}$.

\subsection{Mulur Benang (\%)}

Pengujian mulur benang (\%) dilakukan untuk mengetahui apakah terdapat pengaruh variasi posisi filamen lycra terhadap mulur benang (\%). Pengujian mulur benang dilakukan terhadap 3 variasi yang diujikan, berikut adalah data statistik dari hasil pengujian tersebut.

Tabel 3.5 Hasil Pengujian Mulur B enang (\%)

\begin{tabular}{|c|l|l|l|c|c|}
\hline \multirow{2}{*}{ NO. } & \multicolumn{3}{|c|}{ Posisi Filamen Lycra (\%) } & \multirow{2}{*}{ Standar } & \multirow{2}{*}{ Toleransi } \\
\cline { 2 - 4 } & Tengah & $\mathbf{1} \mathbf{~ m m}$ & $\mathbf{2} \mathbf{~ m m}$ & & \\
\hline $\mathbf{N}$ & 10 & 10 & 10 & - & - \\
\hline $\boldsymbol{\Sigma}$ & 51,66 & 61,58 & 69.26 & - & $-5 \%(4,75)$ \\
\hline$\overline{\boldsymbol{x}}$ & 5,17 & 6,16 & 6.93 & 5,00 & - \\
\hline SD & 0,20 & 0,38 & 0.73 & & - \\
\hline CV & 3,89 & 6,12 & 10.61 & - & \\
\hline E & 2,43 & 3,82 & 6.63 & & \\
\hline
\end{tabular}

Grafik berikut menunjukan nilai mulur benang akibat dari perubahan posisi filamen lycra, berdasarkan grafik diatas, semakin posisi lycra jauh dari posisi tengah maka mulur benang semakin baik. Hal ini karena komposisi lycra di posisi paling jauh yaitu $2 \mathrm{~mm}$ sangat banyak, yang menyebabkan semakin tinggi kemampuan mulur pada benang.

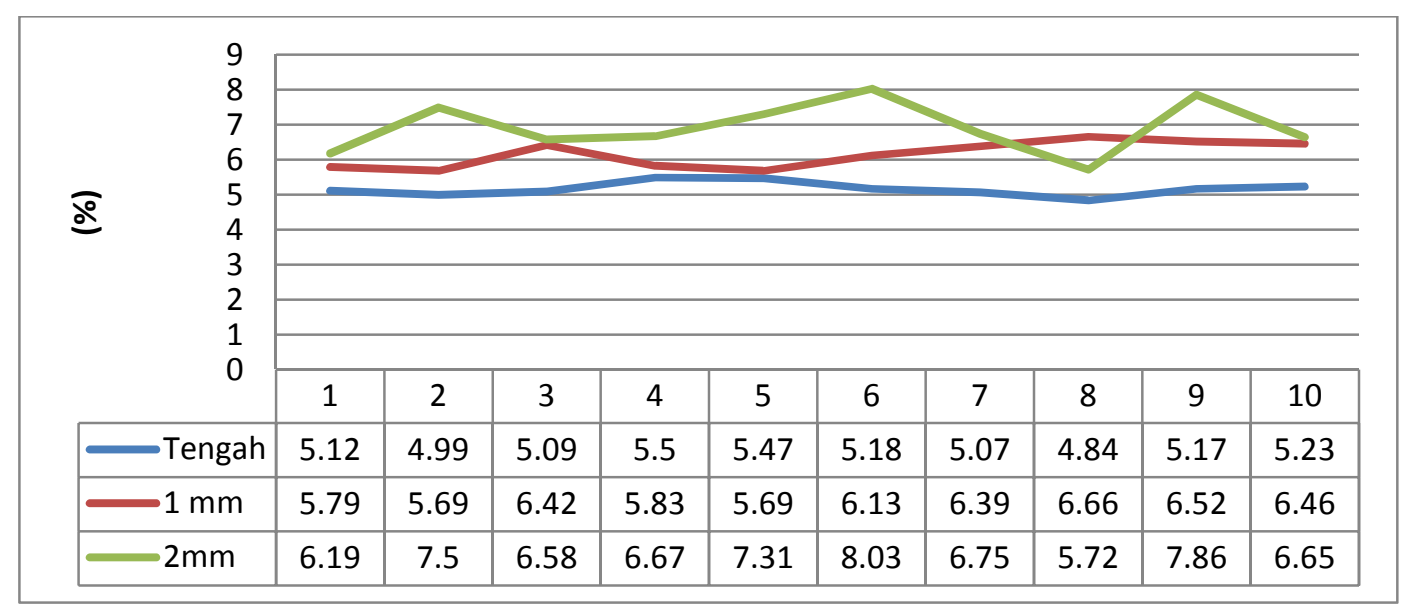




\section{Gambar 3.5 Grafik Mulur Benang (\%)}

Untuk mengetahui sejauh mana pengaruh perbedaan hasil variasi posisi filamen lycra terhadap mulur benang (\%), maka dilakukan pengolahan data statistik dengan menggunakan metoda Analisis Variasi (ANAVA). Pada tabel 3.6 dapat dilihat hasil daftar pengolahan data uji statistitika dengan menggunakan uji anava satu arah mulur benang (\%) dari penggunaan variasi posisi filamen lycra.

Tabel 3.6 Hasil Pengujian Anava Mulur Benang (\%)

\begin{tabular}{|l|r|}
\hline $\mathbf{F}_{\text {tabel }}$ & 3,35 \\
\hline $\mathbf{R y}$ & 1110,21 \\
\hline $\mathbf{A y}$ & 15,57 \\
\hline $\mathbf{D y}$ & 6,50 \\
\hline $\mathbf{Y}^{\mathbf{2}}$ & 1132,28 \\
\hline
\end{tabular}

\begin{tabular}{|l|c|r|r|r|}
\hline Sumber Variasi & DK & \multicolumn{1}{c|}{ J K } & \multicolumn{1}{|c|}{ KT } & \multicolumn{1}{c|}{ F $_{\text {hitung }}$} \\
\hline Rata-Rata & 1 & 1110,21 & 1110,21 & \multirow{2}{*}{32,35} \\
\cline { 1 - 3 } Antar Kelompok & 2 & 15,57 & 7,79 & \\
\hline Dalam Kelompok & 27 & 6,50 & 0,24 & \\
\hline Total & 30 & 1132,28 & & \\
\hline
\end{tabular}

Kesimpulan :

Harga $F$ hitung $(32,35)$ kemudian dibandingkan dengan harga $F$ tabel $(3,35)$. Jadi, $32,35>3.35$ ( $F$ hitung $>F$ tabel), sehingga Ho ditolak dan Ha diterima. Kesimpulannya adalah variasi posisi filamen lycra berpengaruh terhadap nilai mulur benang yang dihasilkan. Untuk mengetahui variasi mana saja yang menunjukkan perbedaan yang signifikan, dilakukan uji Newman Keuls terhadap data diatas. Berikut data uji rentang newman keuls hasil perhitungan.

Tabel 3.7 Uji Newman Keuls Mulur Benang (\%)

\begin{tabular}{|c|c|c|}
\hline & $\mathbf{P}$ & $\mathbf{R S T}$ \\
\hline $\mathbf{2}$ & 2.90 & 0.45 \\
\hline $\mathbf{3}$ & 3.51 & 0.54 \\
\hline $\mathbf{S y}$ & 0.1551 \\
\hline
\end{tabular}

\begin{tabular}{|c|c|c|c|}
\hline Perbandingan & Selisih & RST & Nilai \\
\hline tengah vs $1 \mathrm{~mm}$ & 0.99 & 0.45 & Tolak \\
\hline tengah vs $2 \mathrm{~mm}$ & 1.76 & 0.54 & Tolak \\
\hline $1 \mathrm{~mm}$ vs $2 \mathrm{~mm}$ & 0.77 & 0.45 & Tolak \\
\hline
\end{tabular}

Dari tabel 3.7 di atas, dapat ditarik kesimpulan bahwa ada perbedaan mulur benang per helai dari setiap perbandingan. Perbandingan yang paling signifikan adalah perbandingan antara posisi filamen lycra tengah dengan posisi filamen lycra $2 \mathrm{~mm}$.

\subsection{Ketidakrataan Benang (U\%)}

Pengujian ketidakrataan benang (U\%) dilakukan untuk mengetahui apakah terdapat pengaruh variasi posisi filamen lycra terhadap ketidakrataan benang (U\%). Pengujian dilakukan terhadap 3 variasi yang diujikan, berikut adalah data statistik dari hasil pengujian tersebut.

Tabel 3.8 Hasil Pengujian Ketidakrataan Benang (U\%)

\begin{tabular}{|c|c|c|c|c|c|}
\hline \multirow{2}{*}{ Ket. } & \multicolumn{3}{|c|}{ Posisi Lycra (U\%) } & \multirow{2}{*}{ Standar } & \multirow{2}{*}{ Toleransi (\%) } \\
\hline & Tengah & $1 \mathrm{~mm}$ & $2 \mathrm{~mm}$ & & \\
\hline $\mathbf{N}$ & 10 & 10 & 10 & \multirow{2}{*}{ - } & \multirow{2}{*}{ - } \\
\hline$\Sigma$ & 111.63 & 111.39 & 105.36 & & \\
\hline $\bar{x}$ & 11.16 & 11.14 & 10.54 & 10,80 & $+5 \%(11,34)$ \\
\hline
\end{tabular}




\begin{tabular}{|c|l|l|l|l|}
\hline SD & 0.44 & 0.32 & 0.38 & \\
\hline $\mathbf{C V}$ & 3.94 & 2.90 & 3.64 & - \\
\hline $\mathbf{E}$ & 2.46 & 1.81 & 2.27 & \\
\hline
\end{tabular}

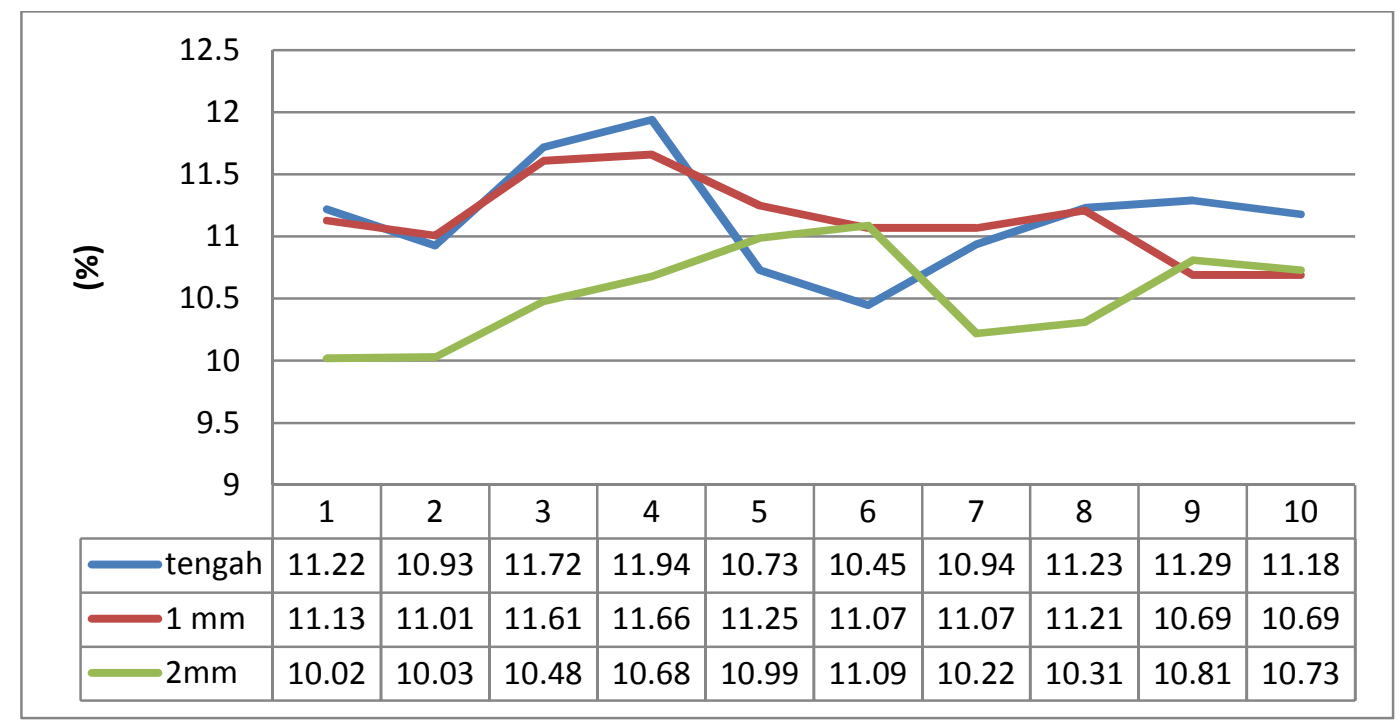

Gambar 3.4 Grafik Ketidakrataan Benang (U\%)

Ketidakrataan menunjukan semakin tinggi nilai ketidakrataan benang maka benang semakin tidak rata, semakin kecil nilai ketidakrataan maka benang semakin rata. Pada posisi filamen $2 \mathrm{~mm}$ menghasilkan ketidakrataan paling rendah, pada posisi $2 \mathrm{~mm}$ posisi benang lycra tidak hanya terbungkus, tapi sebagian benang lycra keluar dan ikut melilit benang pembungkus sehingga menutupi serat-serat yang berada dipermukaan serat kapas sebagai serat pembungkus.

Untuk mengetahui sejauh mana pengaruh perbedaan hasil variasi posisi filamen lycra terhadap ketidakrataan benang (U\%), maka dilakukan pengolahan data statistik dengan menggunakan metoda Analisis Variasi (ANAVA). Pada tabel 3.6 dapat dilihat hasil daftar pengolahan data uji statistika dengan menggunakan uji anava satu arah ketidakrataan benang $(\mathrm{U} \%)$ dari penggunaan variasi posisi filamen lycra.

Tabel 3.9 Hasil Pengujian Anava Ketidakrataan Benang (\%)

\begin{tabular}{|c|c|c|c|c|c|c|}
\hline $\mathbf{F}_{\text {tabel }}$ & 3,35 & sumber variasi & Dk & J K & KT & $\mathbf{F}$ \\
\hline Ry & 3594.45 & rata-rata & 1 & 3594.45 & 3594.45 & \multirow{3}{*}{8.52} \\
\hline Ay & 2.52 & antar kelompok & 2 & 2.52 & 1.26 & \\
\hline Dy & 4.00 & dalam kelompok & 27 & 4.00 & 0.15 & \\
\hline $\mathbf{Y}^{2}$ & 3600.97 & Total & 30 & 3600.97 & - & - \\
\hline
\end{tabular}

Kesimpulan :

Harga $F$ hitung $(8,52)$ kemudian dibandingkan dengan harga $F$ tabel $(3,35)$. Jadi, 8,52>3.35 ( $F$ hitung $>F$ tabel), sehingga Ho ditolak dan Ha diterima. Kesimpulannya adalah variasi posisi filamen lycra berpengaruh terhadap nilai ketidakrataan benang yang dihasilkan. Untuk mengetahui variasi mana saja yang menunjukkan perbedaan yang signifikan, dilakukan uji Newman Keuls terhadap data diatas. Berikut data uji rentang newman keuls hasil perhitungan.

Tabel 3.10 Uji Newman Keuls Ketidakrataan (\%) 


\begin{tabular}{|c|r|r|}
\hline & \multicolumn{1}{|c|}{$\mathbf{P}$} & \multicolumn{1}{c|}{ RST } \\
\hline $\mathbf{2}$ & 2.90 & 0.353262 \\
\hline $\mathbf{3}$ & 3.51 & 0.426787 \\
\hline $\mathbf{S y}$ & 0.12173 & \\
\hline
\end{tabular}

\begin{tabular}{|c|r|r|l|}
\hline Perbandingan & \multicolumn{1}{|c|}{ Selisih } & \multicolumn{1}{c|}{ RST } & Nilai \\
\hline tengah vs $1 \mathrm{~mm}$ & 0.60 & 0.35 & Tolak \\
\hline tengah vs $2 \mathrm{~mm}$ & 0.63 & 0.43 & Tolak \\
\hline $1 \mathrm{~mm}$ vs $2 \mathrm{~mm}$ & 0.02 & 0.35 & Terima \\
\hline
\end{tabular}

Dari tabel 3.10 di atas, dapat ditarik kesimpulan bahwa tidak ada perbedaan ketidakrataan antara posisi filamen lycra $1 \mathrm{~mm}$ dengan $2 \mathrm{~mm}$. Perbedaan ketidakrataan yang signifikan pada perbandingan posisi filamen lycra tengah dangan $1 \mathrm{~mm}$ dan tengah dengan $2 \mathrm{~mm}$.

\subsection{Komposisi Filamen Lycra (\%)}

Pengujian komposisi filamen lycra (\%) dilakukan untuk mengetahui apakah terdapat pengaruh variasi posisi filamen lycra terhadap komposisi filamen lycra (\%). Pengujian dilakukan terhadap 3 variasi yang diujikan, berikut adalah data statistik dari hasil pengujian tersebut.

Tabel 3.11 Hasil Pengujian Komposisi Filamen Lycra (\%)

\begin{tabular}{|c|r|r|r|c|c|}
\hline \multirow{2}{*}{ Ket. } & \multicolumn{3}{|c|}{ Posisi Lycra (\%) } & \multirow{2}{*}{ Standar } & \multirow{2}{*}{ Toleransi } \\
\cline { 2 - 4 } & Tengah & $\mathbf{1 ~} \mathbf{~} \mathbf{m}$ & $\mathbf{2 ~} \mathbf{~ m m}$ & & \\
\hline $\mathbf{N}$ & 10 & 10 & 10 & & - \\
\hline $\boldsymbol{\Sigma}$ & 67.55 & 102.08 & 119.64 & - & $+1 \%(7,07)$ \\
\hline$\overline{\boldsymbol{x}}$ & 6.76 & 10.21 & 11.96 & 7,00 & - \\
\hline SD & 0.57 & 2.45 & 6.97 & & - \\
\hline $\mathbf{C V}$ & 8.48 & 23.96 & 58.30 & - & \\
\hline $\mathbf{E}$ & 5.30 & 14.97 & 36.43 & & \\
\hline
\end{tabular}

Berdasarkan tabel 3.11 nilai CV dan Eror pada posisi $1 \mathrm{~mm}$ dan $2 \mathrm{~mm}$ sangat tinggi bukan di sebabkan karena perhitungan yang salah, tetapi disebabkan data yang tidak konstan, pengaruh benang yang dihasilkan tidak stabil/prosesnya tidak lancar. Untuk mengetahui sejauh mana pengaruh perbedaan hasil variasi posisi filamen lycra terhadap komposisi filamen lycra (\%), maka dilakukan pengolahan data statistik dengan menggunakan metoda Analisis Variasi (ANAVA). Pada tabel 3.12 dapat dilihat hasil daftar pengolahan data uji statistitika dengan menggunakan uji anava satu arah komposisi filamen lycra (\%) dari penggunaan variasi posisi filamen lycra.

Tabel 3.12 Tabel Anava Uji Hipotesis Komposisi Filamen Lycra (\%)

\begin{tabular}{|c|c|c|c|c|c|c|}
\hline $\mathbf{F}_{\text {tabel }}$ & 3,35 & sumber variasi & Dk & J K & KT & $\mathbf{F}$ \\
\hline Ry & 2789.24 & Rata-rata & 1 & 2789.24 & 2789.24 & \multirow{3}{*}{3.83} \\
\hline Ay & 140.47 & Antar Kelompok & 2 & 140.47 & 70.23 & \\
\hline Dy & 494.63 & Dalam Kelompok & 27 & 494.63 & 18.32 & \\
\hline $\mathbf{Y}^{2}$ & 3424.34 & Total & 30 & 3424.34 & - & - \\
\hline
\end{tabular}

Kesimpulan :

Harga $F$ hitung $(3,83)$ kemudian dibandingkan dengan harga $F$ tabel $(3,35)$. Jadi, 3,83>3.35 ( $F$ hitung $>F$ tabel), sehingga Ho ditolak dan Ha diterima. Kesimpulannya adalah variasi posisi filamen lycra berpengaruh terhadap komposisi filamen lycra pada benang yang dihasilkan. Untuk mengetahui variasi mana saja yang menunjukkan perbedaan yang signifikan, dilakukan uji Newman Keuls terhadap data diatas. Berikut data uji rentang newman keuls hasil perhitungan.

Tabel 3.13 Uji Newman Keuls Komposisi Filamen Lycra (\%)

\begin{tabular}{|c|c|c|}
\hline & P & RST \\
\hline $\mathbf{2}$ & 2.90 & 3.93 \\
\hline $\mathbf{3}$ & 3.51 & 4.75 \\
\hline $\mathbf{S y}$ & 1.3535 & \\
\hline
\end{tabular} \begin{tabular}{|c|c|c|c|c|}
\hline Perbandingan & selisih & RST & Nilai \\
\hline tengah vs $1 \mathrm{~mm}$ & 3.45 & 3.93 & Terima \\
\hline tengah vs $2 \mathrm{~mm}$ & 5.21 & 4.75 & Tolak \\
\hline $1 \mathrm{~mm}$ vs $2 \mathrm{~mm}$ & 1.76 & 3.93 & Terima \\
\hline
\end{tabular}


Dari tabel 3.13 di atas, dapat ditarik kesimpulan bahwa tidak ada perbedaan komposisi filamen lycra antara posisi filamen lycra tengah dengan $1 \mathrm{~mm}$ dan $1 \mathrm{~mm}$ dengan $2 \mathrm{~mm}$. Perbedaan ketidakrataan yang signifikan pada perbandingan posisi filamen lycra dan tengah dengan $2 \mathrm{~mm}$.

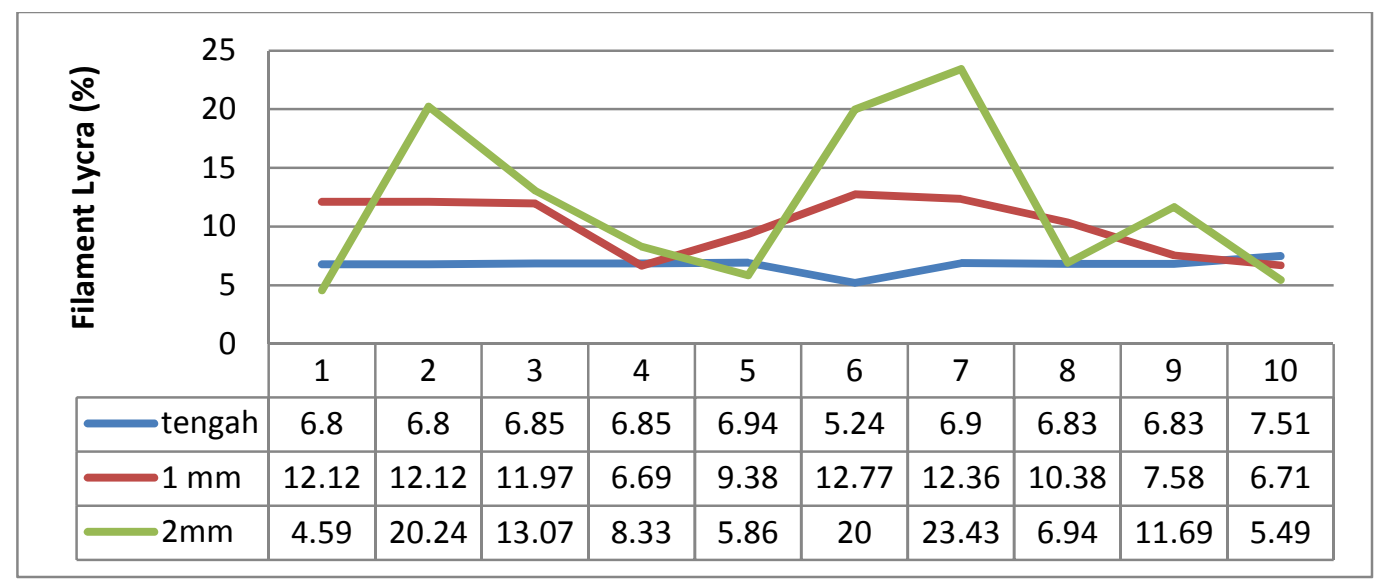

\section{Gambar 3.6 Grafik Komposisi Filamen Lycra}

Berdasarkan grafik diatas dapat terlihat, posisi lycra tengah menunjukan rata-rata komposisi filamen lycra $6,76 \%$, posisi filamen lycra $1 \mathrm{~mm}$ menunjukan rata-rata komposisi filamen lycra 10,21\% dan posisi filamen lycra $2 \mathrm{~mm}$ menunjukan komposisi filamen lycra 11,96\%. Hal tersebut di atas menunjukan bahwa perubahan posisi filamen sangat berpengaruh pada komposisi benang lycra yang dibutuhkan. Pada posisi filamen lycra ditengah, filamen inti (lycra) terbungkus dengan sempurna, sedangkan selain diposisi tengah, filamen inti tidak terbungkus sempurna akibat dari lycra yang ikut melilit kebagian benang.

Berdasarkan 4 pengujian di atas menunjukan peningkatan mutu benang bila posisi filamen semakin jauh dari tengah (posisi $2 \mathrm{~mm}$ ). Berdasarkan hasil pengujian posisi $1 \mathrm{~mm}$ dan $2 \mathrm{~mm}$ menunjukan mutu benang terhadap kekuatan, mulur, ketidakrataan masih memenuhi standar, namun hanya posisi tengah yang komposisi lycranya memenuhi standar. Hal tersebut dapat mengganggu proses selanjutnya yaitu cacat belang pada kain. Untuk menanggulangi pergeseran rol pengantar maka proses maintenance pengontrolan proses harus berjalan secara rutin, dengan sistem perawatan dan tindak lanjut yang jelas pelaksanaanya serta terjadwal, sehingga penanggulangan pergeseran rol dapat ditangani dengan cepat.

\section{KESIMPULAN}

Berdasarkan hasil dari pembahasan dapat disimpulkan bahwa terdapat pengaruh dari posisi filamen lycra pada proses pembuatan benang elastan ( $\mathrm{Ne}_{1} 40$ cotton $+40 \mathrm{D}$ lycra) terhadap mutu benang dengan alat tambahan v-groove di mesin ring spinning Laksmi Rieter.

1. Nilai kekuatan tarik benang tertinggi dihasilkan pada posisi lycra $2 \mathrm{~mm}(16,14 \mathrm{cN} /$ tex $)$. Nilai mulur benang tertinggi dihasilkan pada posisi lycra $2 \mathrm{~mm}(6,93 \%)$. Nilai kerataan benang tertinggi dihasilkan pada posisi lycra $2 \mathrm{~mm}(10,54 \%)$. Nilai komposisi lycra pada benang tertinggi dihasilkan pada posisi lycra $2 \mathrm{~mm}$ $(11,96 \%)$.

2. Posisi filamen yang paling sesuai untuk memproses benang elastan ( $\mathrm{Ne}_{1} 40$ cotton $+40 \mathrm{D}$ lycra) adalah posisi filamen lycra tengah, karena diantara 3 posisi hanya posisi tengah yang komposisi lycranya memenuhi standar. 


\section{DAFTAR PUSTAKA}

1. P. Soeprijono, Serat-Serat Tekstil. Institut Teknologi Bandung, Bandung, 1973.

2. Pawitro dkk., Teknologi pemintalan II, Institut Teknologi Tekstil, Bandung, 1973.

3. Sudjana, Metoda Statistika, Tarsito, Bandung, 2005.

4. Wibowo Moerdoko dkk., Evaluasi tekstil bagian fisika, Institut Teknologi Tekstil, Bandung,1973.

5. www.aatcc.org, Amerika, 2009.

6. http://textileducation.blogspot.com. 